\title{
THE LIMITS OF POSTFIGURATIVE TECHNIQUE IN IGNAZIO SILONE'S PANE E VINO
}

FREDERICK HALE

\begin{abstract}
Sommario
Nella letteratura di '800 e '900 sono state spesso usate figure simboliche di Cristo, ad esempio personaggi la cui vita in vari modi riflette quella di Gesù di Nazaret, pur senza esserne allegorie completamente sviluppate, sono state spesso usate come risorse fittizie, come mezzo di espressione di diverse qualità, lezioni, costumi e valori nel mondo moderno. Uno scrittore che ha usato questa tecnica è Ignazio Silone. Essa forma una parte vitale della struttura del suo romanzo del 1937, Pane e vino. Tuttavia ci sono fondamentali debolezze nell'uso di Silone della figura simbolica di Cristo, il che esemplifica la critica di tale tecnica espressa in generale, fra i tanti, da Liston Pope e Alan Paton.
\end{abstract}

\section{Symbolic Christ Figures as Challenging Literary Phenomena}

Symbolic Christ figures have long played prominent roles in fiction internationally and perhaps reached the zenith of their popularity in the late nineteenth and early twentieth centuries. Not until the 1960s, however, was more than infrequent scholarly analysis undertaken of these characters or their significance defined in terms of literary theory. The emergence of "religion and literature" as a scholarly discipline undoubtedly stimulated both literary scholars and theologians to pay them increased attention during the third quarter of the twentieth century. In one seminal article the eminent South African novelist Alan Paton, whose intensely spiritual Cry, the Beloved Country had appeared in 1948, and Professor Liston Pope, a 
theologian at Yale University, analyzed various efforts to model modern characters on Jesus Christ and concluded that for several reasons such endeavours were almost invariably foreordained to failure. Twentieth-century authors who sought to create such a character, they pointed out, could no longer either assume that readers were familiar with the rudimentary lineaments of the story of Jesus or that they were not; consequently, they ran the risk of writing arcane plots with little symbolic meaning or boring readers with pedantic allegories. Moreover, Paton and Pope cited the limitations posed by a pre-existing plot whose "end is inevitable from the beginning, whatever form the crucifixion may take" and which could thus yield only tragedy if writers were "faithful" to the Biblical account. Such fidelity, however, did not allow a Resurrection in a modern setting. Consequently, "most often in modern fiction the Christ figure is lost 'in the gathering fog' or exiled or executed; we know of no novelist who has undertaken to depict the ultimate triumph." The central character is thus "reduced to a victim of history, largely without hope other than a vague appeal to the future." But beyond these literary limitations, these theologically inclined Christians professed, "Christ is too complex and paradoxical for easy treatment in any of the traditional literary forms, whether tragedy, comedy, melodrama, allegory or fable."1

Their caveat notwithstanding, littérateurs continued to create symbolic Christ figures, if less frequently than they had done during the first few decades of the twentieth century, and in the early 1970s literary scholar Professor Theodore Ziolkowski published what is arguably the most penetrating and far-reaching analysis of this narrative technique. In his Fictional Transfigurations of Jesus he disagreed sharply with the pessimistic conclusions of Paton and Pope. He concurred that in English literature one could point to few

Alan Paton and Liston Pope, "The Novelist and Christ," The Saturday Review, XXXVII, no. 49, 4 December 1954:15-16, 56-59. 
successful Christ figures but argued cogently that fiction in various other languages offered a good many. Acknowledging that he approached "the Gospel story ... as a cultural possession rather than as an item of faith," this esteemed Princeton University scholar reasoned that if one did not insist on full parallelism, but rather looked for characters whose lives were prefigured to a greater or lesser extent by that of Jesus (as, to cite one example, that of James Joyce's Leopold Bloom had been by the Homeric Ulysses in the renowned Irish novel with that title) one could indeed find a cornucopia of laudable examples. Ziolkowski emphasized that his study was not of lives of the historical Jesus two millennia ago or of the various Jesus redivivus stories in which the Man of Nazareth miraculously crops up in the modern world, but rather of "novels in which the life of Jesus has been wholly secularized: it prefigures the life of a fictional character to such a pronounced extent that it determines the structure of entire episodes (as in The Magic Mountain) or, indeed, of entire novels." He developed a carefully refined typological framework for the categorization of such types. The multilingual Ziolkowski cast a broad net and hauled in an abundant catch of European and North American postfigurative examples. ${ }^{2}$

In the present article I shall examine the use of this technique in a novel by Ignazio Silone (1900-1978), an eminent, anti-Fascist writer who became disillusioned with international communism and in various works explored dimensions of his Christian heritage in a quest for common ground between its ethical implications and the goals of socialism. The consideration of his creation of a surreptitious priest who conducts a clandestine campaign against the regime of Benito Mussolini and the 1935-1936 Abyssinian War will be placed into the context of this ideological-spiritual pilgrim's quest for a form of Christianity which would be compatible with his struggle against

2 Theodore Ziolkowski, Fictional Transfigurations of Jesus, Princeton, Princeton University Press, 1972:11. 
Fascism and undergird his vision of social and economic justice. It will be argued that the protagonist of Pane $e$ Vino, while clearly bearing certain hallmarks of a symbolic Christ figure, is woefully developed in this respect and illustrates certain limitations against which theorists like Paton and Pope cautioned. ${ }^{3}$ The theme is an underexplored one in scholarly analysis of Silone's works. Such literary scholars as Murray Krieger have touched on it without evincing an awareness of the most pertinent theoretical literature. ${ }^{4}$

\section{Ignazio Silone as Political Author}

Born in 1900 at Pescina dei Marsi in the Abruzzi, the son of a modest landowner who died young, he was baptised Secondo Tranquilli, (during his exile in the 1930s, he adopted the pseudonym Ignazio Silone in order to protect his family still in Mussolini's Italy). He was educated locally until the age of fifteen when an earthquake killed his mother, who had been a weaver, and two of his brothers. Despite this trauma and the poverty which it exacerbated, he managed to complete his secondary education after going to Rome and entering what he later referred to as "un collegio diretto da zelanti religiosi di un ordine di recente fondazione". 5 There Silone became interested in both politics and journalism. Having been listed in police records as a "subversive" while still a teenager, he became one of the first editors of the weekly Roman Socialist organ Avanguardia and participated in the formation of the Italian Communist Party at Livorno in 1921. In accordance with his ideological convictions, Silone travelled that year to what was then called the Russian Soviet Republic, a journey which

3 Ignazio Silone, Pane e Vino, London, Jonathan Cape, 1937. All parenthetical page references in the text are to this edition.

4 Murray Krieger, The Tragic Vision: Variations on a Theme in Literary Interpretation, New York, Holt, Rinehart \& Winston, 1960: 72-85.

5

Ignazio Silone, Uscita di sicurezza, N.p.: Editori Riminesi Associati, 1994: 22. 
many other western European communists also made in the wake of the Bolshevist Revolution. Returning to Italy, in 1922 he became editor of the communist newspaper in Trieste, Il Lavoratore. After Mussolini's ascendancy the Fascists suppressed left-wing journalism and killed Silone's brother in prison but, apart from periodic political pilgrimages abroad, he remained in Italy, living chiefly among the peasants of the Abruzzi. By the end of the decade he had become disillusioned with communism, however, and, seeing little possibility of effectively opposing Fascism from within Italy, in 1930 quit the Italian Communist Party and settled in Switzerland. From there he conducted a persistent campaign against the regime of Mussolini, using the pen as his weapon of choice. ${ }^{6}$

\section{Silone's Post-Catholic Faith and Relationship to Christianity}

One cannot understand the nature of the message of worldly salvation proclaimed in Pane $e$ Vino and its relationship to the prevailing religious sentiments of the Abruzzi apart from an awareness of Silone's portrayal of Christianity, especially the Roman Catholic Church in Italy during the 1930s. In the wake of the 1929 Lateran Treaty concluded by Mussolini on the one hand and Pope Pius XI and Cardinal Gasparri on the other, the Church's political powers were restricted to the Vatican, which received extensive financial compensation from the Italian government. Catholicism, moreover, had its status as "the sole religion of the state" confirmed in Italy. What apparently mattered most to Silone in this regard was the fact that for all practical purposes the Roman Catholic Church had abjured whatever prophetic voice it may otherwise have raised vis-à-vis the

6 Silone gave a highly insightful and, from the viewpoint of literary history, valuable account of his involvement in and disillusionment with the communist movement in The God That Failed. Six Studies in Communism, London, Hamish Hamilton, 1950: 83-119. 
Fascist government. Consequently, Italians who opposed Mussolini and his cohort who had imposed totalitarian rule on their country found very few allies in the ecclesiastical leadership at any level. Furthermore, many members of the hierarchy not merely tolerated but actively supported the Fascist regime.

Silone's perception of the Catholic establishment left him largely disillusioned with it by the time he had reached early adulthood. Writing retrospectively in the 1960s, he shed invaluable light on the reason for his disaffection and how it had left him with a postecclesiastical faith comprising part of the Christian ethical tradition but shorn of most other dogmatic dimensions. Insisting that his position in this regard was by no means unique, Silone recalled that many Italians of his generation who had been educated at Catholic institutions had left the Church during and shortly after the First World War not because they had rejected its doctrines, "ma spinti da insofferenza contro l'arretratezza, la passività, o il conformismo dell'apparato clericale di fronte alle scelte serie imposte dall'epoca". Most of the clergy, he asserted, were irrelevant to the issues confronting youth at that critical juncture of European history: "In quel periodo di confusione massima, di miseria e disordini sociali, di tradimenti, di violenze, di delitti impuniti e d'illegalità d'ogni specie, accadeva che le lettere pastorali dei vescovi ai fedeli persistessero a trattare invece, di preferenza, i temi dell'abbigliamento licenzioso delle donne, dei bagni promiscui sulle spiagge, dei nuovi balli d'origine esotica e del tradizionale turpiloquio." They had thus abandoned an essential component of their duty: "Quel menare il can per l'aia, da parte di pastori che avevano sempre rivendicato la guida morale del gregge, era uno scandalo insopportabile. Come si poteva rimanere in una simile Chiesa?"”.

7 Ignazio Silone, L'avventura d'un povero cristiano, Milano, Arnoldo Mondadori Editore, 1968: 39-40. 
Silone had found it impossible to return to the religious establishment, even after the aggiornamento of the Second Vatican Council, which he conceded he respected as an important step forward. Nevertheless, by his own testimony he remained "malgrado tutto, un carattere cristiano e socialista". Silone qualified this assertion by declaring that in his view the demythologised kernel of the faith was small yet great: "Rimane dunque un cristianesimo demitizzato ridotto alla sua sostanza morale e, per quello che strada facendo è andato perduto, un grande rispetto e scarsa nostalgia." Apart from this core, he acknowledged that he could accept the Pater Noster, a "sentimento cristiano della fraternità e un istintivo attaccamento alla povera gente ..." Silone's social vision, in other words, determined his definition of Christianity and the extent to which he could accept that religion as his own.

\section{Pane e Vino in Summary}

In brief, Pane e Vino is a political roman à these written to expose certain unsavoury aspects of Mussolini's regime and, apparently, to publicise and galvanise the international campaign to undermine it. Writing from a conventional omniscient narrator point of view, Silone created a brief account of how a somewhat disillusioned Italian socialist, Pietro Spina (into whom the author clearly injected a great deal of himself) returns clandestinely from abroad in 1935 and attempts with little success to contribute to the nearly moribund, antiFascist resistance movement. This sickly protagonist is disguised as a Catholic priest who spends several months in an economically retarded region of the Abruzzi to convalesce, and while doing so he cultivates contacts with the remnants of the socialist movement there and in Rome. Operating under the pseudonym Don Paolo Spada, he finds that most of his erstwhile comrades and schoolmates have compromised their erstwhile political convictions and now lend at least half-hearted support to Mussolini with varying degrees of

Silone, L'avventura d'un povero cristiano: 42. 
sincerity to his nationalist cause. Furthermore, with the exception of a retired, liberally-minded schoolmaster, Don Benedetto, whose favourite pupil he had been, the Roman Catholic Church has also adapted to Fascism in the wake of Mussolini's 1929 Vatican Concordat and has become irrelevant to issues of peace and justice. During Spina's months in Italy, the invasion of Abyssinia is launched. Disillusioned by the willingness of the peasantry of the Abruzzi to support that cause and obstructed by the effectiveness of the government's propaganda machine in intimidating anyone from protesting against it, Spina resorts to writing anti-war slogans furtively on various public buildings, an action which intensifies the authorities' search for him. Eventually, as the net begins to tighten around him, this voice crying desperately in the wilderness attempts to flee through the mountains in the dead of winter. Silone implies that his flight at the close of the narrative is unsuccessful.

\section{The Absence of a Legitimate and Relevant Faith?}

Silone's portrayal of the religious life of Italy, and especially the Abruzzi, during the 1930s is almost entirely unflattering and entirely in accordance with his retrospective comments cited above. Folk beliefs, possibly stemming from before the Christian era and incorporating various superstitions, remain strong in the peasants' minds. "Muore un peccatore di morte violenta, resta qui, nella valle," one local resident tells the clerically clad Spina, in an example of this dimension of the regional mentality. "Lo spirito di chi muore assassinato non ha pace. Sul luogo del delitto, nei primi anni i passanti gettano una pietra, perché lo spirito, possa aver riposo. Voi preti dite il contrario, però è così" (58). In some respects the seemingly Catholic elements also suggest how far the populace has departed from orthodoxy. Spina enquires about a rural chapel dedicated to the Virgin Mary and is told that after a year of natural abnormalities when in the winter month of January roses blossomed, cherries appeared, and ewes gave birth to lambs that edifice had been constructed "affinchè la 
Madonna se ne stia tranquilla" (56). In at least a superficial way, Catholicism, as the official public religion, is omnipresent in Silone's Abruzzi, but alongside the faith of its devout members, anticlericalism is widespread. Moreover, the worshipping laity are almost exclusively women. Silone repeatedly refers to men sending their wives to church while they themselves shun the Mass. This gender gap, to be sure, reflects a demonstrable phenomenon in the life of twentieth-century Italian Catholicism, but it is also a metaphor for the emasculation of the Church in Fascist Italy. Voicing his opinion partly through the sagacious Don Benedetto, who has been forced into retirement after a career teaching classical languages and literature at a Catholic secondary school, Silone establishes early on the acquiescence of the Church to Mussolini's corporate state.

Don Benedetto is a conspicuous exception to the generalised pattern of tacit sacerdotal complicity with Mussolini. His critical attitude towards the cosy relationship between the Vatican and the Fascist government is made clear in the first chapter. This elderly, learned priest, who serves as one of Silone's principal spokesmen in the plot, replies to his sister's query as to why Pius XI refused to comment on the crescendo of war-mongering which would soon lead to the Italian invasion of Abyssinia in October 1935. "Il Santo Padre sa, mia cara, che non è igienico parlare col boccone in bocca," he states acerbically (11). In the same initial chapter, Don Benedetto quizzes one of his former pupils who has become a priest and insists that only "questioni spirituale" should be discussed in the diocesan journal. His erstwhile schoolmaster wonders why such burning contemporary issues as war and unemployment are neglected in that organ (23). Moreover, after spending time in France, Switzerland, and other European countries, Silone clearly did not regard the irrelevance of Christianity as an exclusively Italian phenomenon. In a conversation with another former pupil, Don Benedetto inquires about the whereabouts of Pietro Spina and learns that he has been hounded out of the country because of his opposition to the Fascist government, exiled to an undisclosed 
island and, having escaped from captivity, fled sequentially to Tunisia, France, Switzerland, Luxemburg, and Belgium. Don Benedetto alludes to Matthew 8:20 and/or Luke 9:58 in adding to the construction of this political refugee as a symbolic Christ figure: "Le volpi hanno le loro tane, gli uccelli del cielo hanno i loro nidi, ma il figlio dell'uomo ha nulla sul quale posare la sua testa. Egli continua a vivere secondo i puri sogni della sua adolescenza e i paesi cristiani gli fanno la caccia come ad una bestia infetta" (27).

Subsequently, Silone returns to the theme of the abuse of Christianity for political purposes in Mussolini's dictatorship, principally with regard to its imperialist expansion. As war hysteria mounts in the autumn of 1935, a linkage between the nation's religion and its overseas aspirations is underscored in a ghoulish way. Two gentlemen, bearing as a sign of their political sentiments Fascist party emblems in their buttonholes, share a compartment with Don Paolo on a train between Avezzano and Fossa. One expresses confidence that a "raggio della morte" will allow the Italian forces to overcome the Abyssinian resistance in short order. The other is gratified that " $i$ richiamati di Avezzano saranno oggi benedetti dal vescovo" and is certain that "il 'raggio della morte' aprirà la via ai missionari del papa" (216) Silone's indictment of the church's complicity in fostering popular support for the war continues when he describes a public rally as a pseudo-religious, idolatrous event: "Dal suo rifugio, al di sopra dei tetti delle case circonvicine, egli può anche vedere due o tre campanili, pieni, nelle loro sommità, di ragazzi, come piccionaie gremite di colombi. A un dato momento le campane cominciano a suonare a distesa. La folla è attraversata da membri del partito governativo i quali vanno a porre, attorno all'apparecchio magico, dei feticci patriottici, delle bandiere tricolori, dei gagliardetti neri e un'immagine del Grande Capo, con l'esagerata sporgenza della mascella inferiore" (226). Hammering the point home, the narrator portrays the event as an exercise in mob psychology and politicised paganism. The otherwise cowed crowd chants "un'invocazione 
appassionata al Grande Capo: 'CE DU ! CE DU ! CE DU ! CE DU !'” as a mindless mantra by people who as individuals feel entirely intimidated but find their misdirected strength only when subjecting themselves in hysteric unison to the government's propaganda: "Quel nome che nessuno osa privatamente di pronunziare, né per lodarlo né per maledirlo, perché nominarlo porta disgrazia, ora, nell'adunata collettiva, alla presenza della sua temuta immagine, alla presenza dei feticci della patria, viene gridato e ripetuto con tutta la forza dei polmoni, come per una propiziazione miracolosa, in un religioso delirio: CE DU ! CE DU ! CE DU ! CE DU !" (228).

\section{Unequivocal Signs of the Christ Figure}

It is into this politically oppressive society and bizarrely irrelevant and subservient religious milieu that Silone places his saviour. That Spina is intended to be a kind of symbolic Christ figure who embodies his creator's post-Catholic, socialist version of Christian ethics can hardly be disputed. Some of the signs of this are utterly explicit, while others are strongly implied. To begin with, when Spina returns sub rosa to Italy, he is thirty-three years old, the same age traditionally attributed to Jesus at the time of his crucifixion (23). Very shortly thereafter the seriously ill infiltrator Spina is taken to a barn in order to recuperate out of view of the police who are searching for him, the setting approximates a stereotypical Bethlehem nativity scene: "Si risprofonda dunque nella paglia e se ne sta tranquillo e savio, come il Bambino nel Presepio. Perché l'immagine del Presepio fosse completa bisognerebbe, veramente, che Spina fosse fiancheggiato dall'asino e dalla vacca; nel suo caso l'asino e la vacca ci sono, ma giù nella stalla e solo di notte, perché durante il giorno devono guadagnarsi la paglia" (39). If the livestock are not entirely present, other signs of a divine presence grace the occasion: "Il corpo di Spina è disteso sulla paglia; da un lato c'è una fila di pane, dall'altro un fiasco di vino" (41). Indeed, early on while Spina is residing at Matalena Ricotta's inn in the village of Pietrasecca, a girl from nearby Fossa tells the 
proprietress that her sacerdotal guest could be Jesus himself and explains, "Non sarebbe la prima volta che Gesù si traveste e scende in terra per vedere come vive la povera gente" (77). The bread and wine become a conspicuous Leitmotiv in the narrative, repeatedly being placed on the table when Spina converses with other people. The frequency of this symbolism makes the title of the novel seem entirely natural.

In the last pages of the narrative, the meaning of the two elements is revealed in secular terms which nevertheless embody Silone's understanding of the secular meaning of the Gospel in socialist, antiFascist terms. The father of Murica, a young member of the resistance movement whom police thugs have beaten to death in a scene unmistakably inspired by the scourging and placing on the head of Jesus a crown of thorns in the gospel narratives, provides part of the explanation after feeding beggars who, like Spina, have come to the modest Murica home to offer their condolences. "Dando da mangiare e da bere ai mendicanti, molti han nutrito Gesù senza saperlo," states Murica's mother. The elderly man then states to the indigent guests, "Mangiate e bevete. . . Q Quest'è il suo pane e quest'è il suo vino" (349). In words which are an otherwise unnatural intrusion in the narrative, Spina further explicates the matter: "Il pane è fatto da molti chicchi di grano. ... Perciò esso significa unità. Il vino è fatto di molti acini di uva, e anche esse significa unità. Unità di cose simili, uguali, e utili. Quindi anche verità e fraternità, cose che stanno bene assieme" (349).

\section{The Zenith of Don Paolo's Enlightenment}

It can hardly be overemphasised that Spina does not have $a b$ initio a full comprehension of either the socio-economic realities of Mussolini's Fascist state or an awareness of how certain aspects of the Christian heritage, when shorn of the politicised wool and baneful folk religion with which it has been encumbered, offer an antidote to 
violent, totalitarian oppression. This personal enlightenment comes gradually, and to a great degree Don Benedetto, the liberal Catholic priest and Spina's erstwhile schoolmaster, is the channel through which it is borne. The evolution of the younger man's thought gives Pane $e$ Vino much of its thematic continuity. To some extent, therefore, this is a politico-religious Bildungsroman.

Spina's spiritual development has followed a moderately tortuous course. During his previously mentioned conversation with some of his other former students, Don Benedetto reads from an essay which Spina had written more than a decade earlier. "Se non fosse molto noioso essere posto dopo morto sugli altari, ed essere pregato e adorato da una quantità di persone sconosciute, per la maggior parte vecchie donne brutte, nella mia vita vorrei essere un santo," he had professed. "Non vorrei vivere secondo le circostanze, l'ambiente e le convenienze materiali, ma, senza curarmi delle conseguenze, vorrei, in ogni ora della mia vita, vivere e lottare per quello che a me apparirà giusto e vero" (26). His religious fervour, however, had not remained constant or within the Catholic establishment. Embodying Silone's attitude towards the institutional church, Spina had departed and become a Socialist: "In sostanza egli abbandonò la Chiesa in età ancor giovane, non perché l'avesse intellettualmente o spiritualmente criticata e superata, ma per un risentimento irresistibile contro l'abisso che egli scorse tra quello che essa praticamente faceva e quello che a parole predicava" (92).

Yet Spina has carried with him the seed which Don Benedetto had planted in him, and it germinates after his clandestine return to the Abruzzi. Spina can explain only in part to his erstwhile mentor when the two finally meet in 1935: "Da molti anni ho perduto la fede nell'Eterno [...]. Un impulso religioso mi condusse nel movimento rivoluzionario, ma nel movimento stesso mi son liberato lentamente la testa da ogni pregiudizio religioso. Forse io sono un cattivo rivoluzionario, un rivoluzionario pieno di paure, d'incertezze, di 
complicazioni, a causa appunto di quell'educazione religiosa che ricevetti da ragazzo. D'altronde, senza di essa, sarei mai diventato un rivoluzionario?" (271).

Spina's renewed acquaintance with Don Benedetto, himself increasingly alienated from organised religion, leads him to an awareness that God and the church are not identical. His respect for this priest increases when the latter, in an unveiled allusion to Karl Marx's famous dictum though investing the words with a profoundly different meaning, professes, "La Chiesa ha fatto della verità religiosa un narcotico per la povera gente" (271-272). After Don Benedetto is apparently - poisoned, possibly with the complicity of ecclesiastical authorities, Spina explains to another young revolutionary how the deceased had recently resurrected his post-ecclesiastical, moral faith:

Le parole di don Benedetto sono arrivate allora, corroborate dal tuo esempio, fino al più profondo di me stesso. In pochi giorni c'è stata in me una reintegrazione di tutto ciò che in fondo a me era rimasto ancora vivo e indistruttibile del cristianesimo; un cristianesimo spoglio da ogni mitologia, da ogni teologia, da ogni controllo chiesastico; un cristianesimo che non abdica davanti al Vitello d'Oro, né propone concordati a Ponzio Pilato, né facilita la carriera, ma tutt'al più conduce in carcere, dato che il supplizio della croce non è più in uso. Questa riabilitazione di una parte di me stesso di cui io arrossivo e che cercavo di cancellare o di nascondere, mi dà ora un senso di benessere, anche fisico, che non conoscevo da molti anni, mi dà una forza e un coraggio di cui non mi credevo capace. (316)

Underscoring what he perceives as an overlapping of Christianity and social revolution, Spina explains further: "Per dirla con una vecchia parola, si tratta di convertirsi. Si tratta di diventare un altro uomo. 
Forse basta dire che si tratta di diventare uomo, nel vero senso della parola" (318).

\section{Teaching in Parables}

After finally overcoming most of his inhibitions, Spina, still disguised as the priest Don Paolo Spada and having served as an ecclesiastically illegitimate confessor in Pietrasecca, accedes to the wishes of villagers who gather near the fireplace at the inn there and insist that he tell them stories. Their request on that winter evening provides a longawaited opportunity to plant in them his anti-Fascist gospel of liberation from oppression. It harmonises fully with his liberal understanding of Christianity:

Una storia sempre diversa e sempre uguale. C'è un tempo di crisi profonda. C'è una dittatura con un capo deificato. Una vecchia Chiesa ammuffita che vive di mance. Un esercito di mercenari che garantisce ai ricchi una pacifica digestione. Una popolazione di schiavi. Una preparazione incessante di nuove guerre di rapina per il prestigio della dittatura. Dei viaggiatori misteriosi arrivano intanto dall'estero. Essi parlano sottovoce di prodigi successi in Oriente. Essi annunziano la Buona Novella: la Liberazione è prossima! (323-324)

In Spina's parable, the resulting movement against the regime mirrors the travail of the early church in the Roman Empire:

I poveri, gli affamati, i disperati, si riuniscono in sotteranei per sentirne parlare. La voce si sparge. Dei catecumeni abbandonano la vecchia sinagoga e abbracciano la nuova fede. Dei nobili lasciano i loro palazzi. Dei centurioni disertano. La polizia sorprende delle riunioni clandestine. I prigionieri vengono torturati e deferiti ad un tribunale speciale. Essi affrontano i 
supplizi col sorriso sulle labbra. I giovani vengono gettati alle belvi, i vecchi vengono avvelenati. Quelli che sopravvivono restano fedeli ai morti e tributano ad essi un culto segreto. (324)

\section{The Cost of Discipleship}

In the final pages of Pane e Vino, Silone extends his employment of a symbolic Christ figure to his account of Spina's departure from the Abruzzi and the course which an enthusiastic devotee follows. Informed that the police are closing their net around him, Spina makes preparations to leave the region after sowing the seed of his gospel of liberation from Fascist totalitarian oppression. Though tired, weak, and in poor health, he nevertheless departs on a winter afternoon, ascending a mountainous area with which he apparently has little or no familiarity. Shortly thereafter, his carefully named young follower, Cristina, fearing for his life, pursues him through the snow, bearing wine and bread. Enduring a crescendo of hardship, she repeatedly calls his name but collapses while trying to reach a summit called Sella delle Capre from which she has hoped to see him. In a scene reminiscent of the martyrdom of early Christians thrown to the lions, Silone closes the narrative with these words:

Ad un certo momento una voce le risponde da lontano, ma non è una voce umana. Sembra piuttosto il guaito d'un cane, ma più acuto e prolungato. Cristina lo riconosce: è l'urlo del lupo. L'urlo della carnaccia. Il richiamo agli altri lupi sparsi sulla montagna. L'invito al banchetto comune. E non è carnaccia questa volta, ma carne fina, tenera e pulita che li aspetta, carne battezzata. Attraverso il nevischio e l'oscurità della notte incipiente, Cristina vede accorrere una belva verso di lei, apparendo e sparendo velocemente, attraverso i fossati di neve. Da lontano essa ne vede apparire altre. 
Allora essa s'inginocchia, chiude gli occhi e si fa il segno della croce. (358-359)

\section{Conclusion: The Impossibility of Adapting the Symbolic Christ Figure}

The pessimistic conclusion of Paton and Pope rings true that "most often in modern fiction the Christ figure is lost 'in the gathering fog' or exiled or executed; we know of no novelist who has undertaken to depict the ultimate triumph." This fits Silone's symbolic Christ figure in Pietro Spina virtually hand-in-glove. That the advent of the returned exile in the Abruzzi is modelled after the nativity of Jesus at Bethlehem is only too apparent. Furthermore, as we have seen, there are other elements in Pane e Vino which clearly indicate that Silone uses his Socialist protagonist (as well as Don Benedetto) to voice his understanding of those aspects of the Christian message which reverberate with his goal of social justice. In the end of the novel, however, it proves impossible to harmonise the plot with the victory represented in the death and resurrection of Christ. Spina may ascend to the mountains in an escape which could generously be imagined to be analogous to the Easter event. Furthermore, Cristina's efforts to follow him form a transparent and incomplete modern-day representation of the faith and travail of the early church, and her apparent death clearly mirrors the martyrdom of many Christians. Nevertheless, as Pope and Paton so cogently put it, the central figure is lost "in the gathering fog" and exiled. There is no satisfactory conclusion. The absence of one, of course, reflects Silone's perception of the campaign against Fascism in the mid-1930s. In retrospect, Pane $e$ Vino is a story of its times far more than a twentieth-century manifestation of a timeless story which provided much of its author's interpretation of the human predicament. Silone would take up the theme anew in his first drama (Ed egli si nascose [1944]), whose title is taken from John 8:59 and refers to another case of Jesus Christ's 
encounter with the conservative, collaborationist religious establishment:

"Essi adunque levarono delle pietre, per gettarle contro a lui; ma Gesù si nascose, ed uscì del tempio, essendo passato per mezzo loro; e così se ne andò."

(University of Stellenbosch) 